\title{
Bir Muhalefet Alanı Olarak Toplumsal Cinsiyet Parodisi: Celeste Barber Taklitleri ${ }^{*}$
}

\author{
Didem Narmanlı ve Seyhan Aksoy*
}

Öz

Kültür tarafından belirli cinsiyetlere iliştirilen normatif kurallar olarak tanımlayabileceğimiz toplumsal cinsiyet, sıklıkla kurgusal bir yapı olarak tanımlanır. Toplumsal cinsiyetin normatif kurallar olarak değil bir norm olarak kavranması gerektiğini vurgulayan Judith Butler ise toplumsal cinsiyetin olduğumuz bir şey değil; yaptığımız bir şey olduğunu belirtir. Toplumsal cinsiyetin performatifliğine vurgu yapan Butler, ne bir olgu ne bir hakikat, yalnızca taklit olarak gördüğü bu yapının yapaylığının ancak parodi ile ortaya çıkabileceğini söyler. Bununla birlikte parodinin bu bağlamda bir muhalefet alanı olması onun nasıl alımlandığına bağlıdır. Bu çalışmada ünlülerin fotoğraflarını parodik bir tutumla taklit eden Celeste Barber'ın Instagram paylaşımlarının, moda ve reklam endüstrisi tarafından desteklenen toplumsal cinsiyet stereotiplerini tahrip edici bir nitelik taşıyıp taşımadığının açığa çıkarılması amaçlanmaktadır. $\mathrm{Bu}$ amaçla çalışmada yöntem olarak dijital etnografi uygulanmış ve Celeste Barber'ın Instagram hesabında yer alan parodik paylaşımlarına yapılan takipçi yorumları nitel içerik analizi ile çözümlenmiştir. Sonuçta ise söz konusu hesabın transgresif öğeler taşıyan bir alan olduğu görülmüştür. Egemen ataerkil kültür tarafından kadınlara çizilen sınırların belirginleştiği bir alan olan Instagramda Barber'in hesabı etrafında bir araya gelen kullanıcılar gündelik hayatta kadın olmaya dair sıkıntılarını paylaşmakta ve kendilerine konulan sınırları aşarak egemen olana muhalefet etmektedir. Dolayısıyla bu hesap ataerkil sınırların tartışmaya açıldığı bir transgresyon alanı oluşturmaktadır.

Anahtar Sözcükler: Toplumsal cinsiyet, performativite, transgresyon, parodi, iğrenç

\footnotetext{
* Geliş tarihi: 23/12/2019 • Kabul tarihi: 17/01/2020

** Didem Narmanlı: Süleyman Demirel Üniversitesi İletişim Fakültesi Radyo, Televizyon ve Sinema Bölümü.

Orcid no: 0000-0002-0337-1312, didemcabuk@sdu.edu.tr.

Seyhan Aksoy: Süleyman Demirel Üniversitesi Illetişim Fakültesi Radyo, Televizyon ve Sinema Bölümü.

Orcid no: 0000-0001-5167-5866, seyhanaksoy@sdu.edu.tr
} 


\title{
Gender Parody As a Field of Opposition: Celeste Barber Reenactments*
}

\author{
Didem Narmanlı and Seyhan Aksoy ${ }^{*}$
}

\begin{abstract}
The gender that we can define as normative rules attached to certain genders by culture is often defined as a fictional structure. Emphasizing that gender should be conceived as a norm rather than normative rules, Judith Butler states that gender is not something we are, but something we do. Butler claims that gender is performative. According to her gender is not a fact or a truth, but it forms through imitation and repetition. Butler argues that gender parody reveals the imitative structure of gender. However, the fact that the parody is a field of opposition depends on how it is perceived. This study aims to reveal whether Celeste Barber's Instagram posts, which imitate the photographs of the celebrities in a parodic way, subversive for the gender stereotypes promoted by the fashion and advertising industry. For this purpose, digital ethnography was applied as a method of study. The followers' comments on Barber's posts were analyzed with qualitative content analysis. The analysis shows that this Instagram account has transgressive elements. On Instagram, where the boundaries constructed by dominant patriarchal culture become evident, users gathered around Barber's account share their troubles about being a woman in everyday life and overcome the boundaries set against them and oppose the dominant culture. Therefore, this account creates a transgression area where patriarchal boundaries are subject to discussion.
\end{abstract}

Keywords: Gender, performativity, transgression, parody, abject

\footnotetext{
Received: 23/12/2019 - Accepted: 17/01/2020

* Didem Narmanlı: Süleyman Demirel University Faculty of Communication Department of Radio, Television and Cinema. Orcid id: 0000-0002-0337-1312, didemcabuk@sdu.edu.tr Seyhan Aksoy: Süleyman Demirel University Faculty of Communication Department of Radio, Television and Cinema. Orcid id: 0000-0001-5167-5866, seyhanaksoy@sdu.edu.tr
} 


\section{Bir Muhalefet Alanı Olarak Toplumsal Cinsiyet Parodisi: Celeste Barber Taklitleri}

Toplumsal cinsiyet, kadının ve erkeğin hem fiziksel hem davranışsal olarak nasıl olması gerektiğinin kültür tarafından tarihsel olarak belirlendiği kurgusal bir yapıyı ifade etmektedir. Kadınlık/erkeklik üzerine inşa edilmiş ikili yapısıyla toplumsal cinsiyet kuralları, diğer cinsiyet kategorilerini dışlayan bir alan olması sebebiyle heteroseksüelliğin de meşrulaştırıcısıdır. Aile, okul, medya gibi kurumlar bedenlerin cinsiyetlendirilmesinde aktif rol oynar; makul ve makbul olan tanımlanarak bireylere içinde hareket edeceği sınırlar çizilir. Toplumsal cinsiyet normlarının öğrenilmesi ve benimsenmesinde bu kurumlar aynı zamanda disiplin mekanizması olarak sıklıkla görmezden gelme, aşağılama, dışlama, ötekileştirme ve şiddet pratiklerine başvurur.

Kadınlık ve erkekliğe ilişkin normatif ilkelerle toplumsal cinsiyet, bireylere çeşitli roller üzerinden beklentiler dayatır. Kadın olmak, aslında bir dizi kültürel olasılığı gerçekleştirmektir ve bu sürekli tekrar eden bir etkinliktir (Butler, 1989: 261). Günümüzde kadınlıkla ilişkili kültürel olasılıkların tanımlandığı, biçimlendirildiği ve yeniden üretildiği kurumların başında moda ve reklam endüstrisi gelmektedir (Uncu, 2018: 404). "Bugün bireyleri yoğun olarak etkilemekte olan moda ve reklam, tüm hatlarıyla yumuşak bir otoerotik görüntü oluşturmaya ve bu görüntünün gelişmesini yönlendirmeye çalışmaktadır” (İnceoğlu ve Kar, 2010: 67-68). Böylelikle, kadın, toplumsal onay kazanabilmek için sunulan idollere öykünmeye ve dış görüntüsünü bu idole benzetmesi için çaba göstermeye çağrılmaktadır (Günindi Ersöz, 2010: 46). Bu bağlamda, moda ve reklam aracılığıyla, bedenin bir göstergeye dönüştürüldüğünü ve bu göstergenin makbul olanın tanımlanmasında referans olarak işlediğini söylemek mümkündür.

Tüketim toplumunda beden, bir yandan bireyin toplumsal normlara göre şekillendirmesi gereken diğer yandan da bireyin kimliğini temsil eden bir araçtır. Toplumsal cinsiyet kimliğinin kurucu öğesi olarak özellikle kadın bedeninin bir göstergeye dönüşmesi, bir disiplin mekanizması olarak estetik baskıyı da beraberinde getirmiştir. Referans alınan makbul bedenler gençliğin, güzelliğin, zayıflığın ve sağlığın göstergesi olarak işlerken bunun dışında kalan bedenler kusur ve eksiklik 
göstergesine; kendine bakma, irade ve öz disiplininden yoksun olmanın göstergesine dönüşmüştür (Yumul, 2012: 95). Jean Baudrillard Tüketim Toplumu (1997:160) kitabında güzelliğin kadın için artık dini bir buyruğa dönüştüğünü belirterek, bu estetik baskının, bedenin kullanım değerini değişim değerine indirgeyen bir etik yaklaşımın sonucu olduğunu ifade eder; söz konusu değişim değeri ise "soyut biçimde, görkemli, eksiksiz beden fikrini, arzu ve haz fikrini kendinde toplar."

Moda ve reklam endüstrisi tarafından bedeni üzerinden kadına dayatılan “mükemmellik” projesi, gerçekleştirilmesinin imkânsızlığı nedeniyle, bu projeyi gülünç kılarak itibarsızlaştırmayı amaçlayan toplumsal cinsiyet parodilerine de konu olmaktadır. Bu çalışmada toplumsal cinsiyet parodisine örnek oluşturan Avustralyalı komedyen Celeste Barber'ın Instagram paylaşımlarının, kadınlığa ilişkin egemen algılara bir muhalefet alanı oluşturup oluşturmadığının ortaya konulması amaçlanmaktadır. Celeste Barber'ın Instagram sayfasının seçilme nedeni, yapmış olduğu parodik paylaşımlarla küresel çapta çok sayıda takipçi toplaması ve kamusal bir figür olarak sayfasını feminist eleştiri için kullanmasıdır. Instagram hesabı 5 milyon 600 bin kullanıcı tarafından takip edilen (Nisan, 2019) Celeste Barber "kendini herkesten üstün gören moda meraklılarına sinir olduğunu" belirterek bir röportajda kendisiyle ilgili şöyle demiştir: "Kendimi tamamen feminist olarak tanımlıyorum, farkında olmadan feministmişim. Birdenbire dedim ki ayağa kalkacağım ve bağıracağım çünkü sesim çıkıyor!" (The Guardian, 2017). Bu minvalde Barber, 2015 yılından itibaren moda ve eğlence endüstrisinin popüler figürlerinin Instagram paylaşımlarının parodisini \#celestechallangeaccepted (\#celestemeydanokumayıkabuletti) etiketiyle ve nükteli başlıklarla paylaşmaya başlamıştır. Ünlülerin paylaşımlarının gerçek dışı̆ğını ve sürdürülemezliğini vurgulayarak absürdlüğünü (Slater, vd., 2019: 83) ortaya koymaya çalışan Barber, kadınlığa ilişkin ataerkil kültürün dayattığı kurallarla çizilen sınırları aşmaktadır. Bu bağlamda Barber'ın yaptığı parodik paylaşımlarla yalnızca ünlülere değil, egemen kültüre de meydan okuduğu ve muhalefet ettiği söylenebilir. Bu çalışmada, Barber'ın paylaşımlarının takipçileri için de bir muhalefet alanı oluşturup oluşturmadığının belirlenmesi amaçlanmaktadır. Bu amaç doğrultusunda çalışmada, amaçsal örnekleme tekniği ile 10 paylaşım seçilmiş ve seçilen paylaşımların altına yapılan 38 
bin 534 kullanıcı yorumu üzerinden dijital etnografi yöntemi ile bir çözümleme gerçekleştirilmiştir.

\section{Performativite Olarak Toplumsal Cinsiyet}

Toplumsal cinsiyet 1970'lerden itibaren feminist çalışmaların merkezinde yer alan kavramlardan biridir. Toplumsal cinsiyet ekseninde yapılan çalışmalar, ataerkil toplumsal düzen içerisinde bir kategori ve bir "özne" olarak kadını anlamaya çalışmış ve özgürleşme olasılıklarını tartışmıştır. Simone de Beauvoir'ın Kadın: Ikinci Cins (1949, 1970) adlı eserindeki "kadın doğulmaz, kadın olunur" tespiti, toplumsal cinsiyetin bir edinim olduğuna vurgu yapması açısından bu çalışmaların da veciz ifadesidir. Bu edinim bebeğin cinsiyetinin ilk kez tespit edilmesiyle başlar. Bu tespitle birlikte yaşamlar "kız" ya da "erkek"e göre biçimlendirilir. Anthony Giddens (2008: 209) bu biçimlendirme sürecinin yetişkinler tarafından farkında olmadan işletildiğini bir araştırma üzerinden anlatır. Buna göre; kendi çocuklarına cinsiyetlerine bağlı olarak farklı davranmadıklarını ifade etmelerine rağmen araştırmaya katılan yetişkinlerin aynı bebeğe kız kıyafetleri giydirildiğinde farklı, erkek kıyafetleri giydirildiğinde farklı tepkiler ve oyuncaklar verdiği görülmüştür.

Toplumsal cinsiyetin bu denli içselleştirilmesi onun bir kurgu olduğunun gizlenmesindeki başarıyı göstermektedir. Oyuncakların, renklerin, oyunların, saç ve kıyafet biçimlerinin, duyguları ifade şeklinin, mesleklerin, bedensel biçimlenişin, hazzın, beğenilerin vb., "dişi” ya da "erkek" olmakla arasındaki ilişki deterministik değildir; kültürel olarak kurulur ve öğrenilir. Bu bağlamda toplumsal cinsiyet, erilin ve dişilin ne olduğunun kültürel olarak tanımlandığı ve bu tanımlamaya dayanan düşünceler ve temsiller sistemiyle cinsel kimliğin şekillendirildiği toplumsal roller kümesidir (Thebaud, 2005: 16).

Bununla birlikte Judith Butler (2009), toplumsal cinsiyetin, kadınlık ve erkekliğe ilişkin bir norm olarak kavranmasını önerir. Bu önerinin altında yatan en önemli neden toplumsal cinsiyetin mevcut tanımlanışında kullanılan normatif kuralların erkek/kadın, eril/dişil gibi ikiliklere indirgenmesi sebebiyle tam da itiraz ettiği şeyi doğallaştırmasıdır:

Toplumsal cinsiyet, eril ve dişil kavramların üretildiği ve doğallaştırıldığı mekanizmadır; fakat pekala böyle terimlerin yapısökümünün yapıldığı ve doğallığının bozulduğu aygıt olarak da kullanılabilir. Hakikaten de, normu 
inşa etme çabasındaki aygıtın ta kendisi, aynı zamanda o inşanın altını oymakta kullanılabilir, bir bakıma o inşanın tanımsal açıdan noksan olduğunu gösterebilir (Butler, 2009: 75-76).

Bir norm olarak toplumsal cinsiyetin doğalığının bozulmasında kullanışlı olan özelliği, onun "olduğumuz" bir şey değil de "yaptığımız" bir şey olmasıdır. Yani toplumsal cinsiyet kimliğimiz, bizim içimizde var olan ve dışa vurduğumuz, yansıttığımız bir şey değildir. Aksine; eylemlerin stilize tekrarı yoluyla zamanla edinilen bir kimliktir. Butler, buna toplumsal cinsiyetin performatifliği der. Buna göre toplumsal cinsiyet, içte var olan bir "kendi"liği dışa vuran ya da maskeleyen bir rol değil; insanın kendi psikolojik içselliğinin inşa edilmiş toplumsal kurgusuna dayanan performatif bir eylemdir.

(T)oplumsal cinsiyet çoğunlukla onu kullanan aktörlere hayat veren bir senaryo olarak tekrar tekrar prova edilmiş ancak yine de bir kez daha gerçeklik olarak gerçekleşmesi ve yeniden üretilmesi için bireysel aktörler gerektiren eylemlerdir. (...) Bu tekrarlama, halihazırda toplumsal olarak kurulmuş olan bir dizi anlamın tekrar canlandırılması ve yeniden deneyime sokulmasıdır; meşrulaştırmanın sıradan ve ritüelleştirilmiş şeklidir (Butler, 1988: 277).

Butler'ın performatiflik kavramı toplumsal cinsiyetin, onu gerçek kılan edimlerden ayrı ontolojik bir statüsü olmadığını açıkladığı için önemlidir. Butler’a göre (2008: 224-229), toplumsal cinsiyetin gerçekliğini oluşturan edimler, ifade ve icra biçimleri, bu eylemlere kaynaklık eden bir iç öz etkisi üretse de dışa vuruyor gibi göründüğü özü üretmekte ve yeniden üretmektedir. Öz etkisi, toplumsal cinsiyeti üreten ve disipline eden ideolojik düzenleme ve pratikleri görünmez kılar; toplumsal cinsiyetin ortaya konduğu edimler öz etkisi nedeniyle kavrama içkin, değişmez ya da mutlakmış gibi sunulur. Bu kavramsallaştırmadan hareketle bir öz olarak toplumsal cinsiyetin, gerçeklikten ziyade bir yanılsama olduğu onun performatifliğini açık eden edimlerde görülmektedir. Butler bu noktada drag performansına bir önem atfeder. Drag, performansçının anatomisi ile performansı yapılan toplumsal cinsiyet arasındaki bağlantısızlığa rağmen, neden olarak görünenin bir sonuç olduğunu ortaya koyarak toplumsal cinsiyetin taklide dayalı olduğunu gözler önüne sermekte ve bedeni toplumsal cinsiyetin baskıcı kategorilerinden özgürleştirmektedir. 


\section{Parodi, Transgresyon ve Toplumsal Cinsiyet Muhalefeti}

Butler'a göre, heteroseksüel sistemin ürettiği cinsel konumlar, tam olarak özdeşleşmenin ve gerçekleştirmenin imkânsız olması nedeniyle bir komedidir (Butler, 2008: 206). Butler'ın toplumsal cinsiyet parodisi ${ }^{1}$ olarak adlandırdığı bu durum, kendisini, heteroseksüel kimlik kurgularının heteroseksüel olmayan çevrelerde çoğaltılışında ve yeniden anlamlandırılmasında açıkça göstermektedir. Yasak ve şiddet yoluyla işleyen baskıcı bir yapı olan toplumsal cinsiyete muhalefeti mümkün kılan da bu normatif yapıyı oluşturan unsurlar arasındaki tutarsızlığın parodisidir. Bu bağlamda parodi, cinsiyet ve toplumsal cinsiyet arasındaki ilişkinin yapaylığını gözler önüne seren alt üst edici bir performanstır. Toplumsal cinsiyet parodisiyle;

“(H)eteroseksüel tutarlılık yasasının yerine, cinsiyet ile toplumsal cinsiyetin birbirlerinden ayrı olduklarını teslim eden ve üretilmiş birliklerin ardındaki kültürel mekanizmayı dramatize eden bir performans görürüz ki böylece bu iki terim doğallıktan çıkarılmış olur” (Butler, 2008: 226).

Parodi, bir eserin biçimi bozulmaksızın ona yeni bir içerik vererek öz ve biçim arasında ortaya çıkan karşıtlıktan komik ve eleştirel bir etki yaratmaktır (Yamaner, 2007: 31). Mihail Bahtin, isyankâr özgürlüğüyle Orta Çağ karnavalı olarak gördüğü parodi modelinin özgür konuşmanın tipik örneği olduğunu belirterek parodinin devrimci ve özgürleştirici yönüne vurgu yapmıştır (Moss,1997: 22'den aktaran Brandist, 2011: 205). Aynı minvalde Barry Sanders da Kahkahanın Zaferìnde (2001: 179-184) küçük karnaval kutlamalarını andırdığını belirttiği esprilerin dünyanın sıkıcı, enerjiyi yok edici ve pasifleştirici rutin işlerinin karşısına hayal güçlerini koyarak devrimci birer eylem niteliği kazandıklarını belirtmektedir. Bahtin'e göre Orta Çağ'da yaşam ve ideolojinin tüm resmi alanlarından yasaklarla kovulmuş olan gülme, sahip olduğu itibarsızlaştırıcı sembolleriyle bir yenilik talebine işaret eder (Bahtin, 2005: 109).

Parodiyi politik kılan temel özelliği, konu edindiği değişkenler arasındaki uyumsuzluğu mizahi ve alaycı bir üslupla görünür kılmasıdır; parodik uyumsuzluk yıkıcı

\footnotetext{
1 Butler'ın drag queen örneğinden yola çıkarak tartıştığı toplumsal cinsiyet parodisi anlayışı, heteroseksüel yasanın ve bu yasanın kurallarını temel alan beden-kimlik-politika tartışmalarının yapısökümünü yapan derin bir teorik çerçeve sunar (Bkz. Butler,1998; Butler, 2007; Butler, 2008;). Bununla birlikte toplumsal cinsiyet parodisi kavramı bu yazıda dar anlamda kullanılmıştır.
} 
bir potansiyel taşıyan gülmeyi harekete geçirerek egemen olanın konumunu sarsar ve iktidara meydan okur. Parodiyi politik kılan bir diğer özelliği ise onun transgresif doğasıdır. Genellikle sınırları aşan ya da ihlal eden söylemsel eylemleri tanımlayan transgresyon, aynı zamanda normali ve anormali, sağlıklıyı ve hastalıklıyı, yerliyi ve yabancıyı ayıran ve böylece tanımlayan söylemsel ve maddi çizgileri vurgulayarak sınırları aydınlatmaktadır. Böylelikle transgresyon kimliklere ve toplumsal pratiklere yeni anlamlar kazandırarak ayrım çizgilerini yeniden tanımlamakta ve aşkın derecede bölünmüş olan unsurları melezleştirmeye ya da birleştirmeye, bölünmeleri yok etmeye çalışan uçucu bir güç olarak içkinlikle derin bir kavramsal ilişki paylaşmaktadır (Foust, 2010: 3). Yöntem açısından transgresif bir eylem olan parodi de bu minvalde ilişki kurduğu metnin içerik sınırlarını aşarak onun meşrulaştırdığı sınırları ihlal eder.

Transgresyon dinamik bir olgudur; sınır ve ihlal arasında var olan diyalektik ilişki bir yandan sınırı öte yandan ihlali karşılıklı olarak sürekli yeniler. İhlal, ancak sınırların varlığıyla mümkündür. Sınırların dokunulmazığının arttığı ölçüde ihlal olanakları da artar (Bataille, 2004: 21). Egemen olanın çizdiği sınırlarla görmezden gelinen ve sistemin dışına itilenler transgresif eylemler aracılığıyla görünür olur. Böylelikle transgresyon egemen olanın gücünü ve saygınlığını düşürürken iğrenç (abject) ve grotesk olanı da "normal"leştirir (Langman ve Cangemi, 2010'den aktaran Gürses Akbaykal, 2013: 30).

Kristeva'ya göre (2004: 17), iğrenç ne bir kirlilik ne bir hastalıktır; bir kimliği, sistemi ya da düzeni belirlenen kurallara ve çizilen sınırlara saygı göstermeyerek rahatsız edendir. İ̆renç bedenin tanımlanması, ideal bedenin tanımlanmasıyla mümkündür; ideal beden için çizilen sınırların ötesine geçen ya da berisinde kalan tüm bedenler iğrenç olarak tanımlanmaktadır. Bu nedenle iğrenç bedenler ideal beden sınırlarını ihlal eden, bu sınırlar dışında kalan bedenlerin varlığını görünür kılan ve böylelikle ideal beden kodlarını ve sınırları tartışmaya açarak estetik değerleri yeniden sorgulatan bedenlerdir (Gürses Akbaykal, 2013: 61). Orta sınıf kültürü ve kimliğinin oluşum sürecinden dışlanan ötekinin temsili olarak grotesk beden ise şişmanlatıcı yiyecekler, sarhoşluk veren içkiler gibi aşırılıklarla kirliliğin ve orantısızlığın pürüzlerle dolu maddi bedenidir (Stallybrass ve White 1986'dan aktaran Featherstone, 2013: 143). Bu bağlamda grotesk ve iğrenç bedenler Aydınlanmanın tamamlanmış beden 
kavrayışına ve bu beden kavrayışından hareket eden tüketim toplumunun doğadan uzaklaştırılarak estetize edilmiş bedenlerine meydan okur.

Jane Arthurs (1999: 137-164) Mihail Bahtin'e ve Norbert Elias'a referansla Orta Çağ'da ve feodal toplumlarda beden terbiyesinin toplumsal yaşam, sınıflar ve kültür açısından anlamını tartışarak modern toplumlarda beden politikalarını ve bu politikalara karşı kadınların mizah üzerinden direnişini açıklamaya çalışır. Arthurs'a göre; Elias'ın toplumsal cinsiyete dayalı olmayan açıklamaları, duygusal baskının erkeklerde ve kadınlarda nasıl çalıştığını ayırt etmede başarısız kalmaktadır. Buna göre erkekler bu baskıyı korku ya da hüzün gibi "zayıflık" göstergesi olan duyguların ifadesinde hissederken kadınlar cinsel ve saldırgan hareketlerini erkeklerinkinden daha fazla bastırmak zorunda kalmışlardır. Bu noktada Bahtin'e dönen Arthurs, transgresyonun erkekler için eylem ihlalleri anlamına gelirken kadınlar için sınırlarla sabitlenmiş herhangi bir beden fikrine meydan okuyarak varlıklarını aşmak anlamına geldiğinin altını çizer. Buna göre modern toplumlarda bir toplumsal cinsiyet kategorisi olarak "kadınlığa" meydan okuyan asi kadın, kendisini sınırlaması beklenen yemek ve cinsellik gibi bedensel arzularını tatmin etme hakkını talep eder. Tüm bu nedenlerle komedi, kadınlara çizilen sınırların sorgulanmasının ve hak taleplerinin aracı olarak kadınlar için önemli bir mücadele alanıdır.

Toplumsal cinsiyet parodisi, cinsiyet ve toplumsal cinsiyet arasında deterministik bir ilişki olmadığını gözler önüne sermek için heteroseksüel yasanın "kadın”lara ve "erkek"lere çizdiği sınırları ihlal ederken gülmeye, kahkahaya ve hatta aşırılığa başvurarak bu sınırları itibarsızlaştırmaktadır. Parodinin model olduğu bu transgresif alanda temsil alanının dışına itilen "ötekiler", "anormaller" ya da "sapkınlar" birbirleriyle bir araya gelmekte, toplumsal cinsiyet normlarına meydan okumak üzere birbirlerine ilham olmakta ve bu normlarla dalga geçmektedirler. Bu bağlamda toplumsal cinsiyet parodisi, hegemonik olana bir muhalefet girişimidir. Bununla birlikte, transgresif ve performatif pratikler bir mücadele biçimi olarak toplumsal cinsiyet normlarından özgürleşmenin bir yolu olabildiği gibi iktidarın dışlayıcı ve ötekileştirici söylemini pekiştirmenin bir aracı da olabilmektedir. Örneğin Butler (1993: 126) eğlence amacıyla sergilenen drag performanslarının bazı durumlarda heteroseksüel sistemi alt üst etmek yerine pekiştirdiğini belirtmiştir. Bu bağlamda drag ancak hegemonik toplumsal 
cinsiyetin üretildiği heteroseksüel yapının bir taklit olduğunu doğallık ve aslilik iddialarıyla tartıştığı ölçüde yıkıcı bir edimdir (Butler, 1998: 128).

\section{Bir Muhalefet Alanı Olarak Instagram: Takipçi Yorumlarının Analizi}

Avustralyalı komedyen Celeste Barber'ın Instagram hesabında paylaştığı, toplumsal cinsiyet parodisine örnek oluşturan fotoğrafların, kadınlığa ilişkin egemen algıları ters yüz ederek bir muhalefet alanı oluşturup oluşturmadığının tespitine yönelen bu çalışmada yöntem olarak dijital etnografi kullanılmıştır. Bilgisayar ve iletişim teknolojilerinin hızlı bir şekilde gelişmesi ve toplumsallaşmanın bir alanı haline gelmesi, sosyolojik düşüncenin de dolayımlanmış iletişime dair verinin nasıl toplanacağı ve çözümleneceği hakkında düşünmesini gerektirmiş ve sonuçta dijital ortam, toplumsallaşmanın alanı olurken etnografın da çözümlemekle yükümlü olduğu bir alan haline gelmiştir (Morva, 2017: 145).

Dijital alanın toplumsal bir alana dönüştüğü günümüzde bu alanın araştırılması için antropolojik bir bakış gereklidir. Dijital etnografi, sosyal bilimlerde ve iletişim alanında kullanılan ve nitel bir yöntem olan etnografinin, dijital ortama uyarlanmasıyla ortaya çıkmıştır. Etnografinin çalışma sahası toplum ve kültürdür. Dolayısıyla dijital etnografide de incelenen ortamın topluluk mekânı olarak görüldüğü, etnografik saha ve kültürel ortam olarak kabul edildiği söylenebilir (Hine, 2000). Amaç bilgisayar dolayımlı sosyal toplulukların nasıl oluştuğuna ve etkileşimlerinin doğasına ilişkin çıkarımlarda bulunmaktır.

Etnografide olduğu gibi, dijital ortamda gerçekleştirilen etnografide de temel veri toplama tekniği gözlemdir. Bu çalışmada da Avustralyalı komedyen Celeste Barber'ın Instagram hesabından ilk paylaşımını yaptığı 31.12.2012 ve bu çalışmanın başladığı 15.01.2018 tarihleri arasında yaptığı 919 paylaşımı ve paylaşımlarına yapılan yorumlar gözlemlenmiştir. 919 paylaşımın 817'si fotoğraf, 102'si videodur. 919 paylaşımın 191'i daha çok Celeste Barber'ın düğün, doğum günü ve tatil fotoğrafı ya da videolarından oluşmaktadır. 728 paylaşım ise Barber'ın başkalarının paylaşımlarına ait görselleri taklit ederek alay ettiği parodi içerikli paylaşımlardır. Barber'ın gündelik yaşamına dair kesitler sunması nedeniyle parodi içermeyen kategorisinde değerlendirilen 191 paylaşım ise daha çok Celeste Barber'ın düğün, doğum günü ve tatil fotoğrafı ya da videolarından oluşmaktadır. 728 paylaşımda sunulan parodik içeriğin nesnesi yani 
taklit edilenlerin 234'ü manken, 163'ü televizyon dünyasından ünlü isimler,145’i şarkıcı, 91'i oyuncu, 53'ü anonim kişiler, 18'i manken ve oyuncu gibi birden fazla kişinin gösterildiği içerikler, 16'sı ünlü kişilerin çocukları, altısı modacı/moda ikonu ve ikisi sporcudur. Taklit edilen bu kişilerin, anonim kişiler hariç olmakla birlikte, pek çoğu 'ünlü' kişilerdir. Anonim kişiler de dahil olmak üzere hepsinin ortak özelliği ise toplumsal cinsiyet ve bedene ilişkin kalıp yargıların vücut bulmuş halleri olmalarıdır.

Çalışmanın örnekleminin belirlenmesi iki aşamada gerçeklemiş ve amaçsal örnekleme tekniği kullanılmıştır. Bilindiği üzere amaçsal ya da yargısal örnekleme araştırmacının konuya ilişkin derin bir kavrayış kazanmak amacıyla bir yargıya bağlı olarak belirli kriterlere uyan inceleme nesnesinin seçilmesi sürecini ifade eder (Neuman, 2014: 321-324). Birinci adımda çalışmanın amacı doğrultusunda parodi içeren 728 paylaşım içinden en çok etkileşim alan ve egemen ideolojinin bedenle, annelikle, güzellikle, bakımla ve beslenmeyle ilgili olarak ve kadınlara dayattığı kurallara açık göndermelerde bulunan on paylaşım belirlenmiştir. Belirlenen on paylaşıma ilişkin bilgiler Tablo1'de yer almaktadır. İkinci aşamada ise öncelikle belirlenen on paylaşıma yapılan 38 bin 534 takipçi yorumu kaydedilmiştir. Çalışmada ataerkil kültürle ilişkili olarak dijital ortamdaki takipçi etkileşimlerinin ortaya konulması amaçlandığından yine amaçsal örnekleme tekniği ile bu yorumların içinden 5725 yorum belirlenerek örneklem oluşturulmuştur.

\begin{tabular}{|l|l|c|}
\hline $\begin{array}{l}\text { Paylaşım } \\
\text { Tarihi }\end{array}$ & \multicolumn{1}{|c|}{ Paylaşım Başlığı, Linki ve Açıklaması } & \begin{tabular}{c}
\multicolumn{1}{|c|}{ Yorum } \\
Sayısı
\end{tabular} \\
\hline 21.04.2018 & $\begin{array}{l}\text { FINALLY, Not being able to fit into your clothes is fashionable. Praise } \\
\text { Jesus! } \\
\text { (NiHAYET! Sonunda kıyafetlerin içine girememek moda oldu. İsa'ya } \\
\text { şürler olsun!) } \\
\text { https://www.instagram.com/p/Bhz6MzOhEUs/ } \\
\text { Barber bu paylaşımında Amerikalı model ve Victoria's Secret } \\
\text { meleklerinden biri olarak tanınan Taylor Hill'in 21 Nisan 2018 tarihinde } \\
\text { kendi Instagram sayfasında bir fotoğraf makinesi ikonu ve Manhattan, } \\
\text { New York yer bildirimi ile paylaştığı fotoğrafın parodisini yapmıştır. }\end{array}$ & 1581 \\
\hline 13.02 .2018 & $\begin{array}{l}\text { You gotta hydrate and get naked to stay relevant in Hollywood. } \\
\text { (Hollywood'a kabul edileceksen ıslak ve çıplak olacaksın.) } \\
\text { https://www.instagram.com/p/BfJo0-6B_5p/ } \\
\text { Barber'ın bu paylaşımda parodisini yaptığı orijinal paylaşım daha çok } \\
\text { duygusal ve komedi türü yapımlarda rol alan Hollywood aktristi Selma }\end{array}$ & 3383 \\
\hline
\end{tabular}




\begin{tabular}{|c|c|c|}
\hline 13.02 .2018 & $\begin{array}{l}\text { Blair’a aittir. } 10 \text { Şubat } 2018 \text { tarihinde kendi Instagram sayfasında Blair bu } \\
\text { fotoğrafını New York Moda Haftasını ve ünlü modacı Christian Siriano'yu } \\
\text { etiketleyerek “Jel göz maskelerimle arama kimse giremez. } \\
\text { \#fashionweeknyc @csiriano sizin için hazırlanıyorum” notuyla } \\
\text { paylaşmıştır. }\end{array}$ & \\
\hline 12.02 .2018 & $\begin{array}{l}\text { Quality time with my family really relaxes me } \\
\text { (Ailemle geçirdiğim nitelikli zaman beni gerçekten rahatlatıyor) } \\
\text { https://www.instagram.com/p/BfHHCGNhRın/ } \\
\text { Barber'ın parodisini yaptığı bu paylaşım ünlü Amerikalı şarkıcı, dansçı, } \\
\text { aktris ve model olan Ciara'ya aittir. Ciara'nın Instagram sayfasına } \\
\text { bakıldığında bu pozu Harper's Bazaar Amerika dergisi için verdiği } \\
\text { görülmektedir. Orijinal fotoğraf Ciara tarafından kendi sayfasında } \\
\text { paylaşılmamakla birlikte aynı pozun karşı açıdan görüntülendiği } \\
\text { versiyonunu Ciara sayfasında "Aşk Yenilmezdir \#Family" notuyla } \\
\text { paylaşmıştır. }\end{array}$ & 2547 \\
\hline 05.02 .2018 & $\begin{array}{l}\text { Truth bombs } \\
\text { (Hakikat bombaları) } \\
\text { https://www.instagram.com/p/Be1EDnTB-fl/ } \\
\text { Barber'ın parodisini yaptığı fotoğraf Amerikalı televizyon ünlüsü ve } \\
\text { Victoria's Secret mankeni olan Kendall Jenner'a aittir. Jenner } 1 \text { Şubat } \\
2017 \text { tarihinde bu fotoğrafı kendi Instagram sayfasında "beyzbolda } \\
\text { ağlamak yok" notuyla paylaşmıştır. }\end{array}$ & 6686 \\
\hline 31.12 .2017 & $\begin{array}{l}\text { Weighing up my options for } 2018 \\
\text { (2018 tercihlerimi ölçüp biçiyorum) } \\
\text { https://www.instagram.com/p/BdWKE_HhHo1/ } \\
\text { Bu paylaşımla ilgili Barber herhangi bir etiketleme yapmamıştır. Bu } \\
\text { nedenle parodisini yaptığı fotoğraftaki kişinin kim olduğu ve bu fotoğrafın } \\
\text { hangi bağlamda çekildiği ve paylaşıldığı tespit edilememiştir. }\end{array}$ & 2585 \\
\hline 09.10 .2017 & $\begin{array}{l}\text { BBQ Monthly, changing your perceptions of woman since } 1982 \\
\text { (BBQ Monthly, 1982'den beri kadın algılarınızla oynuyor) } \\
\text { https://www.instagram.com/p/BaCgCSGF997/ } \\
\text { Barber'ın bu paylaşımında parodisini yaptığı fotoğraf Amerikalı aktris, } \\
\text { şarkıcı ve dansçı Bella Thorne'un kendi Instagram sayfasında } 28 \text { Eylül } \\
2017 \text { tarihinde uzun bir açıklama ile paylaşılmıştır. Bu açıklamada } \\
\text { Thorne eleştirilme korkusuna rağmen fotoğrafa rötüş yapılmamasını } \\
\text { istediğini, mükemmel olmadığını, insan olduğunu ve bu tarz } \\
\text { paylaşımların benzer kaygılar taşıyan insanları cesaretlendirmek için } \\
\text { önemli olduğunu söylemektedir. Thorne bu pozu moda, cinsellik, sağlık, } \\
\text { teknoloji ve kültür konularında erkekler için yayınlanan GQ Meksika } \\
\text { dergisi için vermiştir. }\end{array}$ & 2347 \\
\hline 27.09 .2017 & $\begin{array}{l}\text { Sisters by blood. Best friends because we are paid to. } \\
\text { (Kan kızkardeşleri. En iyi arkadaşlarız, zira bize bunun için ödüyorlar.) } \\
\text { https://www.instagram.com/p/BZisımwFxLK/ } \\
\text { Bu paylaşıma konu olan fotoğraftaki kişiler Amerika'nın popüler kültür ve } \\
\text { moda ikonları olan Khole Kardashian ve üvey kızkardeşi Kylie Jenner'dır. }\end{array}$ & 3565 \\
\hline
\end{tabular}




\begin{tabular}{|c|c|c|}
\hline 27.09.2017 & $\begin{array}{l}26 \text { Mayıs } 2017 \text { tarihinde hem Kardashian hem de Jenner tarafından } \\
\text { kendi kişisel Instagram sayfalarında paylaştıkları fotoğrafın orjinali bel } \\
\text { plandır. Kardashian fotoğrafı "KHLOE X KYLIE 5.31.17" başlığıyla; } \\
\text { Jenner ise “ DOLL MATTE LIP yeni Koko Kollection Kit 5/31'in } \\
\text { lansmanı" başlığıyla paylaşmıştır. Fotoğraf Jenner'a ait olan Kylie } \\
\text { Cosmetics firmasının Khloé Kardashian makyaj koleksiyonunun tanıtımı } \\
\text { için çekilmiştir. }\end{array}$ & \\
\hline 09.08 .2017 & $\begin{array}{l}\text { Nothing wrong with a bit of healthy competition } \\
\text { (Sağlıklı bir rekabette yanlış olan hiçbir şey yok.) } \\
\text { https://www.instagram.com/p/BXkAiaHIJBT/ } \\
\text { Barber'ın parodisini yaptığı fotoğraf Amerikalı fotoğrafçı, yoga eğitmeni } \\
\text { ve aynı zamanda sosyal medya fenomeni Naya Rappaport'a aittir. } \\
\text { Rappaport, } 16 \text { Mart } 2017 \text { tarihinde kendi Instagram sayfasında bu } \\
\text { fotoğrafı yoganın kendi hayatındaki yeri ve önemine değinen uzun bir } \\
\text { açıklamayla paylaşmıştır. }\end{array}$ & 4054 \\
\hline 16.07 .2017 & $\begin{array}{l}\text { There's no greater feeling than holding life's most precious gifts } \\
\text { (Yaşamın en kıymetli hediyelerini elinizde tutmaktan daha büyük bir } \\
\text { duygu olamaz.) } \\
\text { https://www.instagram.com/p/BWmW_LalhM5/ } \\
\text { Amerikalı ünlü şarkıcı Beyonce'nin kendi Instagram sayfasında paylaştığı } \\
\text { orijinal fotoğraf } 14 \text { Temmuz } 2017 \text { tarihlidir. Beyonce ikiz bebeklerinin ilk } \\
\text { kez görüntülendiği bu fotoğrafını "Sir Carter ve Rumi bugün } 1 \text { aylık oldu. } \\
\text { A }\end{array}$ & 2423 \\
\hline 30.05 .2017 & $\begin{array}{l}\text { Pancakes and a Sloppy Joe thanks. } \\
\text { (Krepler ve Sloppy Joe, hepinize müteşekkirim.) } \\
\text { https://www.instagram.com/p/BUtUjMwFdpl/ } \\
\text { Barber'ın parodisini yaptığı fotoğraf Amerikalı ünlü model Alexis Ren'e } \\
\text { aittir. Barber'ın farklı tarihlerde kendi Instagram sayfasında birden fazla } \\
\text { paylaşımının parodisini yaptığı Ren bu fotoğrafı } 15 \text { Mayıs } 2017 \text { tarihinde } \\
\text { "Krepler kenara" notuyla paylaşmıştır. }\end{array}$ & 9363 \\
\hline TOPLAM & & 38534 \\
\hline
\end{tabular}

Tablo 1. Seçilen Paylaşımların tarihleri, başlıkları ve yorum sayısı

Takipçi yorumlarının gözlemlenmesi sonucunda ulaşılan verilere, nitel içerik çözümlemesi yapılmıştır. İçerik çözümlemesinde amaç, toplanan verileri açıklayabilecek kavramlara ve ilişkilere ulaşmak ve verilerin içinde saklı olabilecek gerçekleri ortaya çıkarmaktır. Temelde yapılan işlem, birbirine benzeyen verileri belirli kavramlar ve temalar çerçevesinde bir araya getirmek ve yorumlamaktır (Yıldırım ve Şimşek, 2016: 242). Nitel içerik çözümlemesinde kodlama cetveli oluşturulurken tümevarımcı ve veriye dayalı bir yol izlenmelidir (Ackland, 2013: 38). Buna göre 
örneklemde yer alan 5725 yorumun dökümü alınmıştır. Bu yorumlar daha sonra içinde yer alan kelimelere, işaretler e (noktalama işaretleri, emojiler ve etiketler) ve vurgulara (onaylayıcı, alaycı, aşağılayıcı/küçümseyici, ironik) göre kodlanarak ilişkilendirilmiş ve ayrıştırılmıştır. Ardından oluşturulan kodlardan yola çıkarak verileri genel düzeyde açıklayabilecek ve belirli kategoriler altında toplayabilecek temalar oluşturulmuştur. Çalışmanın amacı doğrultusunda oluşturulan özgün çözümleme temaları şunlardır: sanal etkileşim, özdeşleşme, ilham ve transgresyon.

Çalışmada elde edilen bulgular, ${ }^{2}$ oluşturulan temaların başlığı altında verilmiştir. Sanal Etkileşim başlıklı temada yer alan veriler başka kullanıcıları etiketleyerek yapılan ve onları Celeste Barber'ın sayfasını takip etmeye davet eden yorumları içermektedir. Ayrıca kadınlara dayatılan kuralların, ilişkilerin ve popüler kültürün yine başkalarını etiketleyerek karşılıklı olarak tartışıldığı yorumlar da bu temada yer almaktadır. Kullanıcıların kendilerini ya da arkadaşlarını Celeste Barber'ın parodik paylaşımlarındaki durumuna benzeten ve bu paylaşımları kendi hayatlarının yansıması olarak değerlendiren yorumlar Özdeşleşme temasında yer almaktadır. Bir diğer tema olan İlham başlığı altında ise Barber'ın paylaşımlarının kullanıcıların kendi bedenlerine ve ataerkil ideolojinin dayattığı kurallara karşı farkındalığına vurgu yapan yorumlar yer almaktadır. Kullanıcıların eşcinsellik, sarhoşluk, şişmanlık, küfür etmek gibi ataerkil heteroseksüel sistem tarafından modernitenin örnek bireyine getirilen her türlü yasak davranışı benimsediği, aştığı ve yücelttiği yorumlar ise Transgresyon teması altında yer almaktadır. Transgresyon temasında yer alan yorumları diğerlerinden ayıran özelliği bu yorumlarda egemen değerlerin ve çizilen sınırların ihlalinin kutlanması ve bu sınırların bir yandan sorgulanarak öte yandan kahkahalarla ve aşağılayıcı sözcüklerle dalga geçilerek itibarsızlaştırılmasıdır.

\section{Sanal Etkileşim}

Sanal cemaatler internet aracılığıyla ortak ilgileri etrafında bir araya gelen insanların oluşturduğu; duygu ve fikir alışverişi, ticaret, espri, bilimsel tartışma, vs. yapan sosyal gruplardır (Rheingold, 2008). Bu bağlamda değerlendirildiğinde Celeste Barber paylaşımlarının kendi sanal cemaatini oluşturduğu söylenebilir. Celeste Barber'ın

\footnotetext{
2 Bulgularda örnek olarak verilen paylaşımlarda tüm yazım yanlışları ve cümle düşüklükleri korunmuştur. Ayrıca tüm bireysel yorumlar yalnızca tırnak içinde verilirken takipçilerin birbirlerine cevap verdiği ve tartışmaya girdikleri yorumlar tırnak işareti ile verilmiştir.
} 
parodik paylaşımları etrafında toplanan bu cemaatin üyeleri birbirleriyle kadınlığı, güzelliği, anneliği, aşırılığı, ilişkileri tartışmakta, popüler kültür ikonlarının dedikodusunu yaparak dalga geçmekte, gülmekte ve fikir alışverişinde bulunmaktadır.

Çalışmaya dahil edilen paylaşımlara yapılan kullanıcı yorumları çözümlendiğinde Celeste Barber paylaşımlarına getirilen yorumların neredeyse tamamının başka bir ya da birkaç kişiyi etiketleyerek yapıldığı ve hatta etiketlenen kişilere kullanıcılar tarafından bir takip mesajı gönderildiği bulgulanmıştır. Bu durum, sayfanın kullanıcılar arasında bir etkileşim alanı olduğunu göstermektedir. Ayrıca sayfanın takipçisi olmayan kişilerin, arkadaşları tarafından davet edilmesiyle bu alanının giderek genişlediği de görülmektedir. Bu kullanıcılar için Celeste Barber'ın Instagram sayfasının gündelik hayat konuşmalarına da konu olduğu söylenebilir. Örneğin;

“@...... lütfen bana bu pilici takip ettiğini söyle”

“@......... @........ ikiniz de bu sayfaya bayılacaksınız lol"

"@.... sana bahsettiğim kadın bu"

“@....... onunla arkadaş olmalıyız"

Paylaşımlara getirilen yorumlarda çoğunlukla parodisi yapılan fotoğraftaki ünlüler etrafında moda, toplumsal cinsiyet rolleri, güzellik kalıpları ve şöhret eleştirilmekte ve kullanıcılar arasında tartışmalar yürütülmektedir. Bu bağlamda kullanıcıların yorumları üzerinden en çok tartışma "Hollywood'a kabul edileceksen ıslak ve çıplak olacaksın" ve "Yaşamın en kıymetli hediyelerini elinizde tutmaktan daha büyük bir duygu olamaz" başlıklı paylaşımların altında yürütülmüştür. Bu bağlamda incelenen fotoğrafların altına getirilen yorumlardan bazıları şöyledir:

"Cidden ünlülerin kendilerini hazmetmesi ve gerçeklikle bağlantısını koparmaması lazım... kendilerinin yaşamdan daha büyük olduklarını sanıyorlar... teşekkürler @celestebarber”

"@...... Müthiş! İnanıyorum ki öteki piliç sanki bu dünyada çocuğu olan tek kadın oymuş gibi çoktan 2 bebeğiyle birlikte "ben tanrıçayım" pozunu edinmiştir. Ohhhh... Ve Kraliçe ikiz doğurdu!"

"Selma iskelet gibi görünüyor."

-@.....ütfen burada kimseyi utandırmayın. Burayı olduğu gibi olumlu bir alan olarak korumaya çalışın" 
(Yorumu yapan kişiyi etiketleyen arkadaşına yanıt olarak) "-Bunu sevdim. Taklit etmek için doğru resmi seçmişsin. Kadınları toplumun istediği belirli bir köşeye koymak: Eş-Anne-Seksicanavar"

Kullanıcılar tarafından yapılan yorumlara verilen yanıtlar çoğu zaman yoruma etiketledikleri kişilerden gelen onaylayıcı yanıtlardır. Ancak bazı durumlarda bir kullanııının yapmış olduğu yorum diğer kullanıcıların tepkisini çekmekte ve kullanııılar arasında bir tartışma başlatabilmektedir. Kullanıcılar arasında en çok tartışmaya yol açan konu genellikle kullanılan yargılayıcı dilidir. Ötekileştirici, yargılayıcı ve dışlayıcı ifadelerin tartışmaya giren kullanıcıları harekete geçiren etken olduğu görülmektedir. Takipçilerin fotoğrafların altına yaptığı yorumlardan bazıları şöyledir:

"-manken kesinlikle beslenmemiş ve hasta görünüyor...çok çirkin ve sağlıksız bir görünüş.

-bu platformun amacının zayıf kızları ezmek değil, herkesin güzel bir bedene sahip olduğunu söylemek olduğunu düşünüyorum. Herkes farklıdır ve evet en güzel beden sağlıklı olandır. Hakkında hiçbir şey bilmediğin birine gülme alışkanlığı çocukça ve yanlış. Sadece benim fikrim. -hmmmm gevşe -eğer fikrini söylersen o zaman ben de söylerim, yanlış mıyım?"

“-@selmablair genellikle @celestebarber I severim, ama evet paylaşım başlığı kasıtlı. Daha önce onu hiç bu kadar rahatsız edici şekilde eleştirirken görmemiştim.

-gerçekler acıtır ve en çok narsistler gerçeklerden nefret eder. -aslında acıtan zorbalık ve nefret dolu olmaktır. Cahil olduğunu öğrendiğim iyi oldu. Umarım bu çirkin tutumlarını aktaracağın çocukların yoktur."

Dışlama pratikleriyle ilgili olarak paylaşımlara yapılan yorumlardan bazılarında doğrudan Celeste Barber'a eleştiri getirilmektedir. Komedyenin yaptığı çalışmada mizah yoluyla getirilen eleştirinin sistemden ziyade taklidi yapılan kişiye yönelik olduğunu düşünen kullanıcılar yorumlarını kişilerin ötekileştirilmesine karşı duydukları rahatsızlık etrafında şekillendirmiştir. Bazı kullanıcılar ise paylaşımlarda getirilen eleştirinin kişiler üzerinden yapılmasını "kaş yaparken göz çıkarmak" olarak değerlendirmiştir.

“@celestebarber Oyunun ne olduğunu tam olarak anlamadım? Eğer pozun içine etmeseydin sen de eşit derecede seksi görünebilirdin. Bazı kadınlara 
karşı mısın? Hepimiz sadece içinde olduğumuz tüm kadınsal biçimlerimizde birbirimizi takdir edemez miyiz? Bilmiyorum, şu an bir komedyen olduğunu anlıyorum ve beğeni almak için bu boka devam etmek zorundasın ama zarar verici olmuş"

Paylaşımlara yapılan yorumlarda kendine yer bulan bir diğer konu da kadın-erkek ilişkileridir. Kullanıcıların yorumları üzerinden bu minvalde yürüttüğü tartışmaların çoğu "Hakikat Bombaları" başlıklı paylaşımı altında yer almaktadır. Bu yorumlarda genellikle erkeklerin ve erkeklerle olan ilişkilerin sağladığı doyum yiyeceklerle, özellikle zayıflama diyetlerinde kullanımı büyük ölçüde kısıtlanmış olan karbonhidrat ağırlıklı yiyeceklerle kıyaslanmakta ve çoğunlukla karbonhidrat erkeklere tercih edilmektedir. Yapılan erkek/karbonhidrat karşılaştırmasının ölçütü ise yalan, hayal kırıklığı, aldatmak ve anlamaktır.

@penis değil, pizza!

- @.... evet ama ikisiyle de sevgi nefret ilişkimiz var"

"ve karbonhidratlar kesinlikle asla beni hayal kırıklığına uğratmadı!!

Söyleyeyim dedim"

@.... "hayatımızda karbonhidrata ihtiyacımız var, erkeklere değil

-hahahha aman tanrım evvettttt!!

"ekşi mayalı soru sormaz. Ekşi mayalı anlar.

-Ayrıca ekşi mayalı yalan söylemez, aldatmaz, oyun oynamaz"

\section{Bir Özdeşleşme Alanı Olarak Celeste Barber Sayfası}

Kullanıcıların paylaşımlara yaptığı yorumlar incelendiğinde Celeste Barber'ın dayatılan standartların dışarıda bıraktığı kadınların temsilcisi olduğu görülmektedir. Bu standartlar çoğu zaman estetikle, gençlikle ve güzellikle ilgilidir. Paylaşımlardaki parodik canlandırmayı kendileriyle ve içinde bulundukları durumla özdeşleştiren kadınlar paylaşımlar üzerinden kendileriyle eğlenmektedir. Kullanıcıların bu tip yorumları en çok "Krepler ve Sloppy Joe, hepinize müteşekkirim", "Sağlıklı bir rekabette yanlış olan hiçbir şey yok", "NIHAYET! Sonunda kıyafetlerin içine girememek moda oldu. İsa'ya şükürler olsun!” ve “Ailemle geçirdiğim nitelikli zaman beni gerçekten rahatlatıyor” başlıklı paylaşımlara yaptığı görülmektedir.

"Emziren bir anne olduğumdan beri tam olarak böyle hissediyorum!!! "Kaldırdığın" için teşekkürler" 
"Tanrım şükürler olsun! SONUNDA modaya uygunum!"

"Beklentiler vs. gerçekler hahahaha @...."

Estetik ve güzellik konusunda makbul sayılan sınırların dışında kalan bazı kadınların yorumlarda kendilerini "başarısız" olarak algıladığı görülmektedir. Burada başarının ölçütü ise bir pilates sporcusu kadar esnek ve fit olabilmek, ince ve diri olabilmek ve annelik-eşlik rolünü yerine getirirken aynı zamanda her daim bakımlı kalabilmektir. Aşağıda örneği bulunan bu yorumlarda takipçiler daha iyi görünmeye imrendiklerini, Barber'ı "yapamayanlar"ın temsilcisi olarak gördüklerini, bununla birlikte bu durumla dalga geçtiklerini göstermektedir.

“@...... @......@.... havuzdan çıkarken nasıl göründüğüm.

"Keşke göründüğünün yarısı kadar iyi görünseydim Celeste!"

"Yapamayan biz hepimiz için yap! Aferin sana"

"@..... fiziksel aktiviteleri denerken ben"

"Alttaki hayatımı temsil ediyor" Geçen yazdan kıyafetlerimin içine girmeye çalıştıktan sonra bugünkü ben”

Kadınların kendilerini paylaşımlardaki canlandırmayla özdeşleştirdikleri bir diğer konu da anneliktir. Kullanıcılar yorumlarında çoğunlukla anne olmalarıyla birlikte hayatlarının eşlerinin ve çocuklarının beklentileri arasında çıkmaza girdiğine vurgu yapmışlardır. Bu yorumlarda kullanıcılar hayatlarının parçalanmışlığından, kendilerine ayıracak vakit bulamamaktan yakınmaktadır. Bu açıdan annelik kullanıcılar için kutsanan bir olgu olmaktan ziyade kadınların hayatlarından ve güzelliklerinden çalan bir olgu olarak değerlendirilmektedir.

“@..... Ben evde olduğunda ve Arlo yemek istediğinde nasıl hissettiğim” "Bunu daha önce görmüştüm ama beğenme şansım olmamıştı çünkü benim gerçek hayatım aynen böyle görünüyor" "Eğlendirici sevdim. 4 çocuğum var ve aynen resimdeki gibi hissediyorum" "@.... emzirmeden öncesi ve sonrası"

"Emzirme sonrası memeler gerçeği"

Özdeşleşme açısından değerlendirildiğinde kullanıcıların paylaşımları kendi hayatlarının yansımaları olarak gördüğü söylenebilir. Bu hayatlarda kadınların annelik ve eş rolü arasında sıkıştığı, kendi hayatlarından vazgeçmek zorunda kaldığı, uymak zorunda oldukları güzellik kalıplarının dışında kaldıkları için özgüvenlerinin sarsıldığı 
görülmektedir. Bu kadınlar için Celeste Barber kendi seslerini duyuran, yaşadıkları ve hissettikleri konusunda yalnız olmadıklarını gösteren, idealize edilenin imkansızığına vurgu yaparak içinde bulundukları durumun "gerçek"liğini gösteren kişi olarak tüm görmezden gelinenleri temsil etmektedir.

\section{Bir IIIham Alanı Olarak Celeste Barber Sayfası}

Kullanıcılar tarafından yapılan yorumların bazıları Celeste Barber paylaşımlarının kendilerine verdiği ilham etrafında birleşmekte; ilhamın konusu ise çeşitlenmektedir. Bu çeşitlenmede öne çıkan ilk konunun kadınların bedenleriyle barışması olduğu görülmektedir. Paylaşımlara yorum yapan kullanıcıların çoğu bedenlerinden memnun değildir. Bu memnuniyetsizliğin birincil sebebi ise sahip oldukları ölçülerin moda dünyasının sunduğu güzel kadınların ölçüleriyle uyuşmamasıdır. Bu bağlamda paylaşımlara yorum yapan kullanıcılar çoğunlukla bu zamana kadar bedenlerinden duydukları memnuniyetsizliğe vurgu yaparak paylaşımların beden algıları üzerindeki olumlu etkisini dile getirmişlerdir.

"Öğret bana bilge kadın. Sayende kendim olmakta daha özgür olabiliyorum. Hahaha"

"Evet muhteşem. Kadınların fazla kilolu olmalarıyla barışmasını sağlıyorsun"

"Mutlu yıllar @celestebarber!!! Kahkahalar için sana teşekkür ederim. Ve kendim olmamda bir sorun olmadığını hissetmeme yardım ettiğin için teşekkürler. Sen en iyisisin"

"@celestebarber Hepimizin Hollywood yıldızı olabileceğimizi fark ettirdiğin için teşekkürler"

"Dürüst olarak söylemek gerekirse beni daima gülümsetiyor ve kendimle ilgili daha iyi hissetmemi sağlıyorsun"

"Seni seviyorum Celeste. İçin de dışın da çok güzel ve sen bize en önemli şeyin öz saygı olduğunu gösteriyorsun. Hepimiz için ortalığı salla!!

"Meydan okumaların için sana teşekkür ederim, kendi bedenimle tatminkar olmam gerektiğini fark etmeme yardımcı oluyorlar"

"Çok güzelsin, bize kendi bedenlerimizi takdir etmeyi öğrettin. Devam et." "Harikasın! Gerçekçi imajların ünlülerin çekimleri kadar güzel olduğunu gösterdiğin için teşekkürler."

Paylaşımlara yorum yapan kullanıcıların çoğu kendi bedenlerine ve güzellik kavrayışlarına ilişkin farkındalıklarını arttırdığı yönünde Celeste Barber’a teşekkür 
etmektedir. Bu kullanıcılar tarafından Celeste Barber bir "rol model", "erk hayvanı", "kahraman" ve "idol" olarak nitelendirilmektedir. Aynı zamanda bu kullanıcılar için Celeste Barber moda ve güzellik kurallarıyla dalga geçen asi, isyankâr bir kadın olarak da bir ilham kaynağı olarak görülmektedir.

"Aman tanrım, seni çok seviyorum. Sen ne şaşırtıcı bir rol modelsin" "Etiket bu kadın bizim ruh rehberimiz"

"Kahramanım.... \#bless"

"Kız, bir ikonsun!!!"

“@...... bunu görmüş müydün? Bu bir isyan!"

"oh sen cidden bir başkaldırısın."

Celeste Barber'ın, kapitalizmin ve ataerkil ideolojinin popüler kültür aracılığıyla özellikle kadınlara dayattığı kulları alt üst ederek, kullanıcılara yalnızca bireysel sıkıntıları açısından değil bu bireysel sıkıntıların da nedeni olan toplumsal kurguyu fark etmeleri açısından ilham olduğu görülmüştür. Bu kullanıcıların yorumlarındaki memnuniyetsizlik vurgusu kendi bedenleri üzerine değil; içinde yaşanılan dünyada hakim olan kurallar ve standartlar üzerinedir. Bu kullanıcılar için paylaşımlar, bir yandan içinde yaşaması dayanılmaz bir hal alan modern dünyanın kadınlar için dayattığı kuralların akıl dışılığını göstermesi öte yandan da bu dünyanın baskılarının kadınlar üzerinde yarattığı stresi mizah yoluyla azaltması açısından değerlidir.

"Paylaşımlarına kesinlikle bayılıyorum!! Genç kızlarıma göstererek bir noktaya dikkat çektim böylece Instagramda gördükleri sahte ıvır zıvırların elde edilemez olduğunu biliyorlar, ne yazık ki Kardishian laneti güçlü ama çare sensin!!"

"Bu yüzeysel dünyanın nasıl bu kadar aptal olduğunu göstermene bayılıyorum."

"ah celeste dünya için bana umut veriyorsun"

"Taze hava solumak gibisin!"

"Yaptığın her şeyi seviyorum. Beni çok güldürüyorsun! Ne zaman kendimi stres altında hissetsem sayfana gidiyorum. "

"Her zaman eğlenceli bir yolla içinde yaşadığımız modern toplumda gözlerimizi açmamıza yardım ettiğin için teşekkürler"

"Hepimiz biliyoruz ki biri diğerinden daima büyüktür. Seni ve mizah duygunu seviyorum!!!"

“@ ...... bu kadın benim akıl sağlığımı koruyor”

\footnotetext{
3 İngilizce "Spirit animal" kelimesinin karşılı olarak kullanılmıştır. Spiritüel gelişimde insana yaşam boyu rehberlik eden öğretici anlamına gelir.
} 
Her ne kadar kadınlara dayatılan moda kurallarıyla ilgili çoğunlukla kadın kullanıcıların yorum yaptığı görülse de konuyla ilgili feminist eleştiri getiren erkek kullanıcıların yorumları da göze çarpmaktadır. Bu yorumlardan ilki, Butler'ın (2008: 206) heteroseksüel sistemin ürettiği ve gerçekleştirmenin imkansız olduğu cinsel konumlarla özdeşleşme çabasının komediye yol açtığı tespitiyle örtüştüğü için önemlidir.

\begin{abstract}
"Paylaşımlarınla ilgili her şeyi seviyorum. Kadınların eğlenceli olmadığı klişesini yıktın. Bunun ötesinde toplumun saçma sapan fotoşoplu ve gerçekdışı güzellik standartlarına meydan okuyorsun ve "gerçek" fotoğraflar komediye dönüşüyor. Ayrıca bbq fetişini normalize etmemize yardım ettiğin için teşekkürler. Lanet olsun, paylaşımlarının neden şaşırtıcı olduğunu erkekledim ${ }^{4}$ mi? Ataerkillik bana da zarar verdi."

"Bu en iyisi @celestebarber açıkça fantastiksin. Dünyadaki tüm kızlar not alın; sen hepimizin bayıldığı kadın tipisin. Cesur, neşeli, gerçek ve tamamen histerikçe eğlenceli. Senin gibi baş belası kadınlar için şükürler olsun. SAYGI"

"nemlen, soyun VE aptal bir yüz ifadesi takın, başka hiçbir şeyin önemi yok" "Bunu yapan yüzlerce kadın olmasını dilerdim! Yeterince göremiyorum"

"Devam et kızım! Gerçek ol! Paylaşımlarını seviyorum! Sahte hiçbir şey yok!"
\end{abstract}

Paylaşımların ilham verdiği konulardan bir diğeri de fotoğrafların yeniden canlandırılmasıdır. Paylaşımlara yaptıkları yorumlarda arkadaşlarını etiketleyen kullanıcılar bazen paylaşıma konu olan orijinal fotoğrafı bazen de Celeste Barber'ın parodik versiyonunu yeniden canlandırmak istemektedir. $\mathrm{Bu}$ bağlamda Celeste Barber'ın hem parodisini yapmak üzere seçtiği fotoğraflarla hem de kendi parodik yorumuyla takipçileri için paylaşacakları fotoğrafların biçim ve içeriğini belirleyen bir ikon olduğu söylenebilir. Orijinal versiyonu canlandırmak isteyen kullanıcıların estetik motivasyonunun, parodik versiyonu canlandırmak isteyen kullanıcıların ise eğlence motivasyonunun harekete geçirici olduğu görülmüştür.

“@..... yaptığımız gebelik çekimlerinde bana ilham veren fotoğraflardan biriydi” "hahahahahahahah @...... hala göbeğin varken böyle bir resim çektirmelisin!!! Lütfen”

\footnotetext{
4 İngilizce "mansplain" kelimesinin karşıığı olarak kullanılmıştır. Man ve explain kelimelerinin birleşiminden oluşan ve feminist aktivistler tarafından sosyal medyada oldukça sık kullanılan bu kelime erkeklerin her konuda bilir kişi olarak açıklama yapması ve kendi aklını yüceltmesini ifade etmektedir.
} 
“@...... aynısını yapalım"

"Hahahahahahaa bunu limonlarla denemeliyim"

"hahahahaha @..... bizimkini yapalım"

İlham başlı̆̆ı altında değerlendirildiğinde Celeste Barber paylaşımlarının özellikle kadınlar için umut veren, öz saygıyı arttıran, sorun çözücü bir alan olduğu söylenebilir. Bu bağlamda değerlendirildiğinde kullanıcılar açısından yorumlara yansıyan birbiriyle ilişkili iki Celeste Barber olduğu görülmektedir. Bunlardan biri modern dünyanın ve ataerkil ideolojinin açmazlarını mizah yoluyla gösteren ve dayatılan kuralları sorgulamalarını sağlayan "yaramaz", "başbelası" ve "dahi” Celeste Barber'dır. İkincisi ise böylelikle "norm dışı" kadınların özgüvenini yerine getiren ve eğlenmelerini sağlayan bir rol model, rehber ya da kahraman olan Celeste Barberdır. Bu bağlamda Beyonce'un fotoğrafının parodik versiyonunda elinde hayatın en kıymetli hediyeleri olarak tuttuğu ekmek ve içki şişesiyle ya da bedeninin tüm "kusurlarını" sergileyerek toplumsal cinsiyet açısından eril bir alan olarak tanımlanan barbeküye ve $G Q$ dergisine gönderme yapan dergi adı ve elindeki maşayla, Celeste Barber paylaşımlarınının Arthurs'un (1999) tartıştığı gibi bir toplumsal cinsiyet kategorisi olarak kadınlığa meydan okuyan, varlığını aşan ve bedensel arzularının tatminini talep eden transgresif bir eylem olduğu görülmektedir.

\section{Bir Transgresyon Alanı Olarak Celeste Barber Sayfası}

Kullanıcıların paylaşımlara yapmış olduğu yorumlar incelendiğinde Celeste Barber sayfasının kadınlığa ilişkin normatif kurallar ile moda endüstrisinin güzellik kalıpları tarafından dışlanan bireylerin seslerini duyurduğu ve bu kurallar tarafından kadınlara çizilen sınırların aşıldığı bir transgresyon alanı olduğu görülmektedir. Bu transgresyon alanında kullanıcılar kadına ve kadınlığa ilişkin tüm kalıplarla dalga geçmekte, sınırları aşmakta ve "yasak" olan her şeyi kucaklamaktadır. Yorumlar üzerinden değerlendirildiğinde heteroseksüel yasa, moda endüstrisi ve normatif toplumsal kurallar tarafından yasaklanan eşcinsel ilişki, karbonhidrat ve alkol tüketimi, küfür ve nezaket kurallarının ihlaline kullanıcılar tarafından vurgu yapıldığı görülmektedir. Bu bağlamda takipçiler tarafından yapılan yorumlardan bazıları şöyledir: 
"Erkekler yalan söyler. Kızlarla çıkın."

"Lmao5!!! Karbonhidratlar ve şarap hayatın hazineleridir!!! \#başardım"

"Evet!!! Karbonhidratlar ve alkol!"

"Her zaman dediğim gibi....hiçbir pantolon en iyi pantolon değildir.

Giymediğin müddetçe hepsi daima uyar hahahah Şimdi izninle egzersiz yapmaya, kendime gülmeye ve evimin konforunda osurmaya gideyim böylelikle spor salonunda gülmem."

$\mathrm{Bu}$ alanda kucaklanan diğer unsurlar ise yasaklanmamakla birlikte kaçınılması gereken aşırılıklardır. Kullanıcı yorumlarında aşırılıklarla ilgili fark edilen ilk durum gülmeye ilişkindir. Kullanıcıların yorumlarında gülmeyi ifade etmek için kullandığı emojiler değerlendirildiğinde iki emojinin öne çıktığı ve neredeyse tüm kullanıcılar tarafından yoğun olarak kullanıldığı görülmektedir.

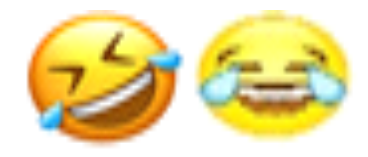

Şekil 1: Sık Kullanılan Kahkaha Emojileri

Kullanıcıların yorumlarında paylaşımlara verdiği tepkiler açısından kahkaha emojileri ile birlikle "Iol", "Imao/Imfao", "rofl” gibi kısaltmaları kullandıkları da belirtilmelidir. Bu bağlamda yorum yapanların paylaşımlardaki parodiyi kahkahalarla cevaplayarak "çatlayana" kadar "yerlere yatarak" gülmeleri ve böylelikle egemen olanın çizdiği sınırları itibarsızlaştırmaları nedeniyle sayfayı bir transgresyon alanına çevirdikleri söylenebilir.

"Neredeyse gülmekten altıma işedim"

"Gerçekten smoothiemi püskürttüm"

Bu transgresyon alanında kullanıcılar başta ataerkil ideoloji ve onun simgeleri olmak üzere paylaşımlarda moda endüstrisinin güzellik kalıplarını temsil eden modellerini ve yine bu kalıpların egemen hale gelmesinin aracısı olan popüler kültür ikonlarını itibarsızlaştırmaktadır. Kullanıcıların itibarsızlaştırma stratejisi olarak gülmenin

\footnotetext{
5 "Iol", "Imao/Imfao", "rofl" gibi kısaltmalar "gülmekten çatladım", "gülmekten kaba etlerim ağrıdı",
} "gülmekten yerlere yattım" olarak çevrilebilen İngilizce ifadeleri oluşturan kelimelerin ilk harfleridir. 
yanında paylaşımlardaki orijinal fotoğraflarda yer alan kişilerle dalga geçtiği görülmektedir.

\begin{abstract}
"Arabanın motor kapağına çizilen fallik sembol! ROFL!" "Bebekler B'nin kollarında cipse dönmüş"

"Bunu sevdim!! Soldaki çoook fotoşoplu. Beli kafasından küçük!! Sen güzelsin Celeste!!"

"Ananas dikenlerinin olmaması gereken bazı yerler vardır. "Meme uçları" bu listenin en başındadır"
\end{abstract}

Gülme dışında kullanıcıların yorumlarında başka aşırılıklara da kucak açtığı ve böylelikle transgresif anlamda kendilerine çizilen sınırları ihlal ettikleri görülmektedir. Bu sınırların ihlal edildiği alan ise beden alanıdır. Kullanıcılar yorumlarında moda endüstrisi tarafından idealize edilmiş bedenlere meydan okuyarak bu ideal bedenin dışında kalanı yüceltmektedir. Bu bağlamda yorumlarda kullanıcıların grotesk ve iğrenç bedenleri bu transgresyon alanında görünür ve meşru kılarak tüketim toplumunun estetize edilmiş beden kavrayışına meydan okuduğu (Featherstone, 2013) söylenebilir. İdeal bedenin karşıtı olarak "kusurlu" bedenle birlikte yorumlarda çirkin ya da ucube olarak nitelendirilen ve moda endüstrisi kalıplarının dışında kalan diğer öğelerin de kabul edildiği görülmektedir.

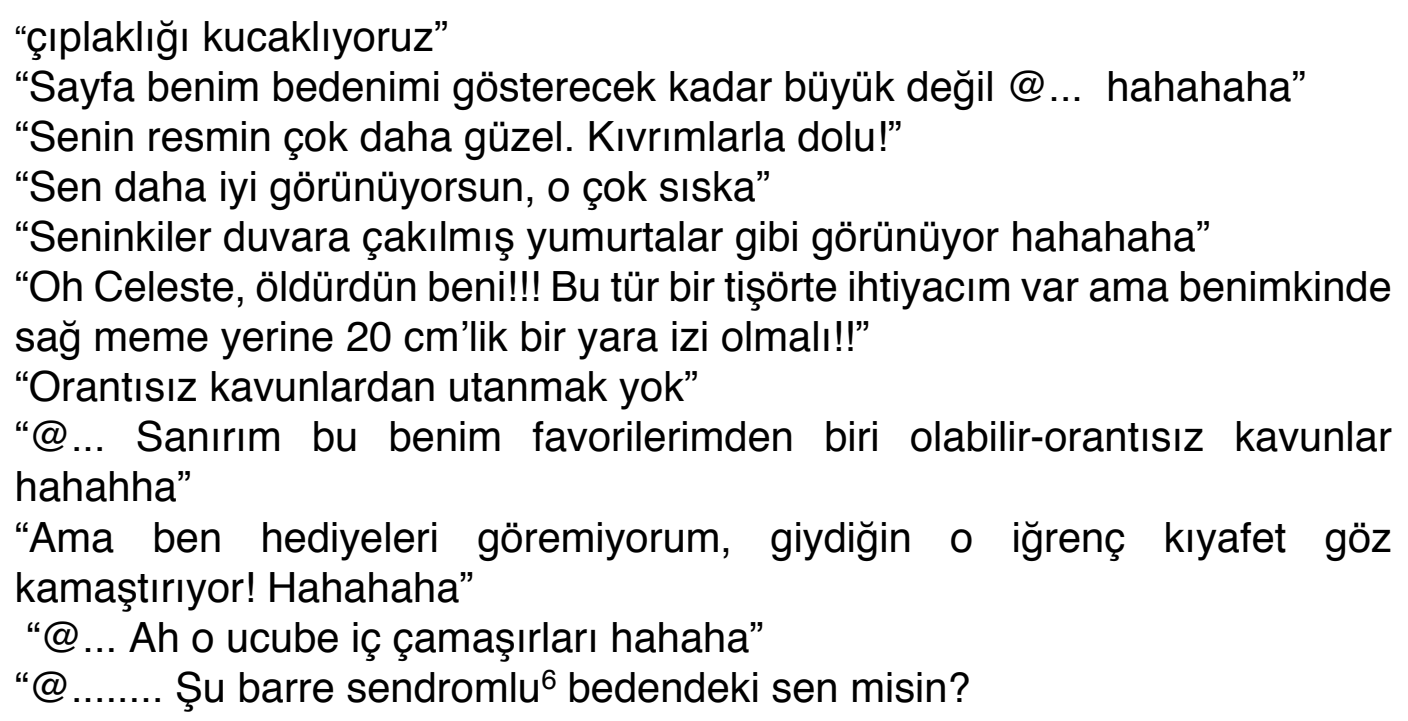

Kullanıcıların paylaşımlara yaptığı yorumlarda transgresif öğeler açısından dikkati çeken bir husus da egemen değerlerin, kısıtlamaların, yasakların ve ataerkil iktidarın

\footnotetext{
${ }^{6}$ Guillain-Barre sendromu (GBS) ilerleyici kas zayıflığı veya felciyle seyreden otoimmün bir hastalıktır.
} 
kahkahalarla ve aşağılanarak itibarsızlaştırıldığı ve yaşamın, şişmanlatan ve sarhoşluk veren yiyecek ve içeceklerin ve tüm aşırılıkların kutsandığı bu alanda karnavalesk öğelerle siyasal iktidara muhalefet etmeleridir. Kullanıcılar yorumlarında Bahtin'i (2005) hatırlatarak, "resmi dünyaya karşı kendi dünyasını, resmi kiliseye karşı kendi kilisesini, resmi iktidara karşı kendi iktidarını" kurmuş ve bu iktidarın kraliçesi olarak bir komedyen olan Celeste Barber'ı seçmiştir.

"Harika! @celestebarber Başkan olsun”

“@....... Kraliçe C!!

"Kraliçe C!"

“@.....başkanlık için Celeste hahahaha”

Kullanıcıların yaptığı yorumlarda heteroseksüel ataerkil ideolojinin koyduğu sınırları itibarsızlaştırması, bu sınırları aşması ve böylelikle sınırları görünür kılarak tartışmaya açması sayfanın transgresif bir alan olduğuna işaret etmektedir. Yorumlarda ayrıca iğrenç ve grotesk olanın yüceltilerek resmi iktidara meydan okunması nedeniyle sayfanın karnavalesk özellikler taşıdığı da söylenebilir.

\section{Sonuç}

Bu çalışmada moda ve popüler kültür ikonlarının fotoğraf ve videolarını parodik bir şekilde yeniden canlandıran Celeste Barber'ın Instagram sayfası incelenmiş ve bu paylaşımlara yapılan kullanıcı yorumları sayfanın egemen kadınlık kurallarına bir muhalefet alanı oluşturup oluşturmadığı sorusu çerçevesinde çözümlenmiştir. Celeste Barber'ın paylaşımlarını parodik kılan özelliği komedyenin yeniden canlandırma performanslarında beden ve davranış arasında endüstri tarafından doğalmış gibi gösterilen ilişkinin yapaylığını gözler önüne sermesidir. $\mathrm{Bu}$ bağlamda değerlendirildiğinde Barber, bir cinsiyet kategorisi olarak “kadın”ın Butler'ın (1988) da belirttiği gibi olunan bir şey değil; yapılan bir şey olduğunu ve ayrıca sahip olunan bedenin başka birçok davranış seçeneğini de barındırdığını açığa çıkartmaktadır. Bunu yaparken kullandığı strateji ise "başarısızlık"tır. Celeste Barber'ın bir "kadın" bedenine sahip olması, parodisini yaptığı fotoğraflardaki ikonların zerafetine, 
seksapeline, inceliğine de sahip olmasını ve anneliği kutsayıp yüceltmesini sağlayamamıştır.

Kapitalizm, kadınlara ataerkil ideoloji temelinde popüler kültür ve tüketim kültürünün de aracılığıyla erkeklere her konuda hizmet etmek üzere daima hazır olmaları gerektiğini söylemektedir. Bu bağlamda kadınlar kendi hayatlarını yaşamak ve yaşamdan doyum almakla "kadın” olarak omuzlarına yüklenen görevleri yerine getirirken her daim genç, ince, fit ve dinç olmak arasında sıkışıp kalmıştır. Bu imkânsız görevi başarmaya çalışan kadınlar kendilerini yoğun bir stres ve baskı altında hissederken aynı zamanda hiçbir zaman tam olarak başaramamaları nedeniyle eksik, kusurlu ve başarısız hissetmektedir. Slater, vd., (2019: 86) de yapmış oldukları çalışmada Celeste Barber'ın parodik paylaşımlarını takip eden kadınların, yalnızca ünlülerin kusursuz beden imajlarına ait paylaşımları takip eden kadınlara oranla kendi bedenlerinden daha fazla memnuniyet duyduklarını ve daha mutlu olduklarını ortaya koymuştur.

Celeste Barber paylaşımları her şeyden önce kadınların kendi hayatlarının yansımalarını gördüğü bir alan olarak karşımıza çıkmaktadır. Bu anlamda kadınların hayattan talep ve beklentilerinin yok sayılarak omuzlarına yüklenen imkânsız görevleri yerine getirmeye çalışmasının parodisini yapan komedyen, paylaşımlarında sürekli "başarısızlık" sergilemektedir. Gündelik hayat içerisinde yaşadıkları baskı ve stresi anlayan ve sürekli kendileri gibi başarısız olan bir kadının varlığı etrafında toplanan diğer kadınlar için paylaşımlar öncelikle bir rahatlama alanıdır. Bu alanda sanal olarak bir araya gelen kadınlar aslında başarmaya çalıştıklarının imkansızlığına gülerek ve yalnız olmadıklarını fark ederek üzerlerindeki baskının etkisinden biraz olsun kurtulmaktadır.

Başta kadınlar olmak üzere komedyenin paylaşımları etrafında bir araya gelen bireylerin paylaşımlara verdiği ortak tepki kahkahadır. Emojiler ve kısaltmalarla ifade edilen kahkaha Bahtin'in (2005: 38) de belirttiği gibi hem yenileyici ve yaratıcı bir etkinlik hem de yıkıcı bir arzu içermektedir. Ayrıca takipçilerin hem alay hem zafer hem övgü hem yergilerinin ifadesi olarak yorumlanabilen müphem kahkahaları tam da bu minvalde politik bir eylemdir. Takipçilerin kahkahaları bir yandan moda ve reklam endüstrisi tarafından dayatılan makbul kadın bedeni ve davranışlarını alay ederek itibarsızlaştırırken öte yandan bu endüstri tarafından çizilen sınırın ötesinde kalan tüm 
dışlanmışların zaferini kutlamakta ve yerleşik kurallarda bir yenilik talebinin ifadesi olmaktadır.

Celeste Barber parodik paylaşımlarında sürekli olarak estetize edilmiş ideal bedenin karşısına kendi "iğrenç" (abject) bedenini konumlandırarak bedenin tamamlanmamışlığını ortaya koymaktadır. Bu anlamda Barber, anaakım alanın sınırları dışına itilen grotesk ve iğrenç olanı temsil etmektedir. Takipçilerin paylaşımlara yapmış olduğu yorumlarda güzel ve çirkin, sağlıklı ve hastalıklı, normal ve anormal arasındaki sınırlar bir yandan yıkılırken bir yandan görünür kılınmakta ve aşılmaktadır. Bu bağlamda Barber'ın sayfası Christina R. Foust'un (2010) tartıştığı şekliyle bir transgresyon alanıdır. Tüm bu bulgular ışığında Celeste Barber'ın Instagram sayfasında bir araya gelen kullanıcıların gündelik hayatta kadınlığa ve egemen kadınlık hallerine dair sıkıntılarını paylaştığı ve kendilerine konulan sınırları aşarak egemen olana muhalefet sergilediklerini söylemek mümkündür. 


\section{Kaynakça}

Ackland, Robert (2013). Web Social Science: Concepts, Data and Tools for Social Scientists in the Digital Age. London: Sage

Arthurs, Jane (1997). "Revolting Women: The Body in Comic Performance." Women's Bodies Discipline and Transgression Jane Arthurs ve Jean Grimshaw (der.) içinde. London: Cassell. 137-164

Bahtin, Mikhail (2005). Rabelais ve Dünyası. Çev., Çiçek Öztek. İstanbul: Ayrıntı.

Bataille, Georges, (2004) Edebiyat ve Kötülük. Çev., Ayşegül Sözmezay. İstanbul: Ayrıntı.

Baudrillard, Jean, (1997). Tüketim Toplumu. Çev., Ferda Keskin ve Nilgün Tutal. İstanbul: Ayrıntı.

Brandist, Craig (2011). Bahtin ve Çevresi: Felsefe, Kültür ve Politika. Çev., Cem Soydemir. Ankara: Doğu Batı.

Butler, Judith (2009). "Toplumsal Cinsiyet Düzenlemeleri." Cogito, 58: 73-91

Butler, Judith (2008). Cinsiyet Belası. Çev., Başak Ertür. İstanbul: Metis.

Butler, Judith (2007). Taklit ve 'Toplumsal Cinsiyet'e Karşı Durma. Osman Akınhay (Çev.). İstanbul: Agora Kitaplığı

Butler, Judith (1998). "Toplumsal Cinsiyet Yanıyor Sahiplenme ve Yıkma Sorunları." Defter, 34: 123-141.

Butler, Judith (1993). Bodies That Matter. London:Routledge

Butler, Judith (1989). "Gendering the Body: Beauvoir's Philosophical Contributions." Women, Knowledge and Realit. Ann Garry ve Marilyn Pearsall (der.) içinde. Boston: Unwin Hyman. 253-262.

Butler, Judith (1988). "Performative Acts and Gender Constitution: An Essay in Phenomenology and Feminist Theory." Theatre Journal, 40(4): 519-531.

De Beauvoir, Simone (1970). Kadın: Ikinci Cins 1. Cilt Genç Kızlık Çağı. Çev., Bertan Onaran. İstanbul: Payel Yayınları.

Günindi Ersöz, Aysel, (2010). "Tüketim Toplumunda "Sıfır Beden" Söylemi: Neden ve Sonuçları Üzerine Sosyolojik Bir Değerlendirme." Edebiyat Fakültesi Dergisi, 27(2): 37-53.

Featherstone, Mike (2013). Postmodernizm ve Tüketim Kültürü. Çev., Mehmet Küçük. İstanbul: Ayrıntı. 
Foust, Christina R. (2010). Transgression as a Mode of Resistance. Lanham: Lexington Books.

Giddens, Anthony (2008). Sosyoloji. Cemal Güzel (der.). İstanbul: Kırmızı.

Gürses Akbaykal, İlknur (2013). Transgresyon ve Anarşi: Fotoğrafta Aşırılığın Estetiği.

Ege Üniversitesi Sosyal Bilimler Enstitüsü Radyo, Televizyon Sinema Anabilim Dalı, Yayınlanmamış Doktora Tezi, İzmir.

Hine, Christine (2000). Virtual Ethnography. London: Sage.

İnceoğlu, Yasemin ve Altan Kar (2010). Dişilik, Güzellik ve Şiddet Sarmalında Kadın ve Bedeni. İstanbul: Ayrıntı.

Kristeva, Julia (2004). Korkunun Güçleri İğrençlik Üzerine Deneme. Çev., Nilgün Tutal. İstanbul: Ayrıntı Yayınları.

Morva, Oya (2017). “Chicago Sosyoloji Okulu'nun Etnografik Mirasını Yeniden Okumak: Dijital Etnografi Çağında Sembolik Etkileşimcilik.” Moment, 4(1):135154.

Neuman, W. Lawrence (2014). Toplumsal Araştırma Yöntemleri Nitel ve Nicel Yaklaşımlar I. Cilt. Çev., Sedef Özge. Ankara: Yayınodası.

Rheingold, Howard (2008). "Virtual Communities: Exchanging Ideas Through Computer Bulletin Boards." Journal of Virtual Worlds Research, 1(1): 1-5. https://journals.tdl.org/jvwr/index.php/jvwr/article/viewFile/293/247. Erişim tarihi: 27 Mayıs 2018.

Sanders, Barry (2001). Kahkahanın Zaferi: Yıkıcı Bir Tarih Olarak Gülme. Çev., Kemal Atakay. İstanbul: Ayrıntı.

Slater, Amy, Natasha Cole ve Jasmine Fardouly (2019). "The Effect of Exposure to Parodies of Thin-Ideal Images on Young Women's Body Image and Mood." Body Image 29: 82-89.

Thebaud, Françoise (2005). "Toplumsal Cinsiyet Araştırmaları.” Çev., Ahmet Fethi. Kadınların Tarihi: Yirminci Yüzyılda Kültürel Bir Kimliğe Doğru Cilt 5. Georges Duby ve Michelle Perrot (der.) içinde. İstanbul: Türkiye İş Bankası Kültür Yayınları. 13-24.

The Guardian, (2017). "Celeste Barber: 'I get miffed with fashionistas thinking they are better than others'” https://www.theguardian.com/culture/2017/jun/30/celeste- 
barber-i-get-miffed-with-fashionistas-thinking-they-are-better-than-others, Erişim tarihi: 20 Ekim 2017.

Uncu, Gonca (2018). “Reklam'da Kusursuzluğa Dayalı Kadın İmgesi: 'Neden O’nun Gibi Görünmüyorum?"' Akademik Sosyal Araştırmalar Dergisi, 76: 402-423.

Yamaner, Güzin (2007). Postmodernizm ve Sanat. Ankara: Algı Yayınları.

Yıldırım, Ali ve Hasan Şimşek (2016). Sosyal Bilimlerde Nitel Araştırma Yöntemleri. Ankara: Seçkin.

Yumul, Arus, (2012). "Ötekiliği Bedenlere Kaydetmek." Ayrımcılık: Çok Boyutlu Yaklaşımlar. Kenan Çayır ve Müge Ayan Ceyhan (der.) içinde. İstanbul: Bilgi Üniversitesi Yayınları. 89-96. 